\title{
Reviving Egalitarianism in the Global Transformation: Building Occupational Security
}

\author{
Guy Standing*
}

\begin{abstract}
The world is in the midst of a Global Transformation, reflecting the painful creation of a global market society. Globalization was the disembedded phase, in which inequalities and insecurities multiplied as national systems of regulation, social protection and redistribution were dismantled or broke down. This reflected the collapse of labourism and systems of industrial citizenship, and an end to the building of national welfare states as the development objective. The outcomes were unsustainable. But what should be the counter-movement by which the global economic system will be re-embedded in society? This article suggests that a new approach to social and economic security is required, one that places work and occupation at the centre of life rather than labour, and one in which universal basic economic security is the primary development objective. In order to move in that direction, this article advocates the use of five policy decision principles by which all policies and institutional changes should be evaluated. It concludes by sketching a progressive strategy oriented to occupational citizenship, giving equal respect to liberty, equality and fraternity, or social solidarity.
\end{abstract}

\section{INTRODUCTION}

In April 2005, an international conference was convened in New Delhi by the Institute for Human Development on income security and employment security. It was graciously opened by the President of India. At the time, there was what seemed excessive hope and euphoria being placed in the new Indian Government and, in particular, in the Common Minimum Programme (CMP). It seemed misconceived, going against the grain of a realistic progressive vision for the twentyfirst century, in India or any other part of the world.

On offer was a paternalistic policy package, which was neither egalitarian nor universalistic. The answer to the woes of those being left behind by what had been foolishly called 'shining India' was 'guaranteed employment'. Even if this had performed precisely as its designers claimed it would, it amounted to a charitable promise of a spell of doing unattractive labour for unattractive pay.

Progressives everywhere need to fight against paternalistic tendencies, which often stem from their own class backgrounds. They must combat their paternalistic demons if they are to forge a new model that will appeal to the emerging socioeconomic groups. In India and elsewhere, escape from paternalism remains an extraordinarily difficult feat. The sense of social hierarchy is so deeply ingrained that an agenda for universalism and rights is always in danger of becoming an exercise in

\footnotetext{
* Professor of Economic Security, University of Bath, UK; Professor of Labour Economics, Monash University, Australia; and Co-President, Basic Income Earth Network (BIEN)
} 
hypocrisy or one of spewing more elegant prose designed to impress the reader with the writer's erudition.

The biggest source of failure of the main twentieth-century progressive model, social democracy, was its overwhelming emphasis on labour. This set up a trio of asset-control conflicts that made universalism impossible-between those representing labour and those representing capital, between those performing labour and those doing economic activity outside the standard employment relationship (SER), and between those performing labour and those doing kinds of work that yielded no direct income. It also cemented an implicit social compact-a social deal of structured inequality-between those performing labour in the SER and those earning most of their income from rent or from productive or financial capital. The state supported and built on that compact, leaving the rest in a position of disadvantage.

Part of the deal was that SER employees would be protected by labour law, trade unions, collective bargaining and protective regulations while a sociodemographic hierarchy would continue-with lower income security and other forms of security being given to women, migrants, ethnic minorities, lower castes and others deemed to be outsiders. The welfare states built on those premises were designed to make the outcomes sufficiently stable as to be sustainable. No welfare state was built on universalism or equal basic security for all its citizens. Indeed, the common claim that welfare state capitalism constituted a 'golden age' oriented to labour decommodification is one of the biggest intellectual misrepresentations in modern history. One notices that almost all apostles of this view have been men.

One last introductory point is in order. When in the early 1980s, I first argued that economic insecurity was an emerging crisis associated with open economies and labour market flexibility, there were few voices of support. Most said it was a passing phase. My thesis was and remains that economic insecurity is actually wanted by the orthodox economic doctrine, and that we are in the midst of a Global Transformation, analogous to Karl Polanyi's Great Transformation, in which old systems of regulation, redistribution and social protection have broken down, resulting in mass inequalities and insecurities. These outcomes are non-sustainable, but the old systems will not solve the problem.

Polanyi's Transformation was about the painful forging of national markets, above all about the institutional shaping of national labour markets. We are now in the midst of an even more painful process, the creation of an international market system. Contrary to what some observers claim, this is not analogous to the period before 1913; we should look to the emerging characteristics and class configurations for a progressive response, rather than to the past.

\section{AN EGALITARIAN APPROACH TO SECURITY}

A progressive agenda should be concerned with the enhancement of freedom and with equality. For too long, progressives of the world have been frightened by 
freedom, and have been prone to advocate soft or hard paternalism. In the words used by the Indian President at the opening of the Conference on Income Security in 2005, too often progressives, as well as others, have wanted to be visible leaders rather than invisible facilitators of full freedom.

All theories of justice are built on the belief in the equality of something. The most credible position is that there should be an equal right to basic economic securitynot equal incomes, not equal wealth, but an equal claim or republican right to basic security. The term 'claim right' signifies that policies should move progressively towards this right.

How can security be defined? I have used the terms socio-economic security and economic security (Standing, 2002; ILO, 2004). Others have used the term human security, which seems rather sweeping. Let us not quibble about that here. In abstract, security is the ability to survive, reproduce and develop in conditions of adequate, stable and predictable support, providing circumstances in which to develop human capabilities. The risks, uncertainties and hazards to which people are exposed should be such as to be tolerable, and everybody, regardless of social or economic status, should have the means not only to cope with but also to recover from adverse shocks and the hazards of life. Note that a security agenda must be concerned with ameliorating all four aspectsrisks, uncertainty, hazards and shocks.

Debates about alternative forms of social protection have assumed an urgency because globalization and economic informalization appear to involve more pervasive economic insecurity and inequality. The character of the insecurity has changed too. Identifying that is a necessary aspect of identifying appropriate policies, and their likely effects on livelihoods and work patterns.

Briefly, economic insecurity reflects exposure to several forms of risk and uncertainty and a limited capacity to cope with adverse outcomes and to recover from those outcomes. To a greater or lesser extent, any individual is exposed to idiosyncratic risk, that is, the risk of an adverse event that reflects life-cycle contingencies such as a spell of unemployment, a work-related accident or illness, or a disabling accident. This is the sphere of classic social security schemes. There is also co-variant risk, that is, where a risk of one adverse event is tied to the risk of others, where one adverse event has a high probability of precipitating one or more other mishaps.

This leads to the distinction between shocks and hazards. Shocks have become more numerous due to globalization and global warming. Included are sharp economic downturns that sweep whole communities, economies or regions. There are circumstances that one can characterize as socio-economic disasters, whether they be quick-onset disasters, as in the cases of earthquakes, floods, tsunamis or a sudden economic collapse, or slow-onset disasters, as in the case of famines, droughts or an epidemic such as HIV/AIDS, which threaten the livelihoods and reproductive capacity of whole communities.

Situations of shock should be distinguished from hazards, which are important 
sources of economic insecurity in developing countries, and which may be defined as predictable (often desired) life events that have a high probability of an indirect adverse effect, or a sequence of adverse effects, for an individual or family. They include the death of a relative, weddings, births, a migration event, and retirement. A well-known hazard to which Indians are exposed with a potentially catastrophic outcome is the marriage of a daughter, due to the costs involved. They may be joyous events, but for some families on the margin, they are hazardous.

With both shocks and hazards, the resultant costs could erode a household's capacity to sustain its livelihood base, perhaps by pushing it into debt, into mortgaging land or by preventing it from buying seeds or fertilisers. Given the high probability of such events, an insurance policy would entail high premiums or would not be feasible. For some types of event, an insurance scheme would involve a moral hazard, that is, the prospect of a compensatory payment would make it more likely that the event would occur. This would mean that an insurer would wish to monitor people's behaviour and the amount of compensation would be linked to proof of actual costs associated with the event or to some predetermined acceptable level of costs to be covered.

Economic insecurity also arises from uncertainty. With uncertainty, one is unsure about one's actual interests or how to realize them. The outcome of decisions cannot be predicted with confidence; often this is combined with a perceived inability to know what to do if an adverse outcome materializes. A high degree of uncertainty pushes people into more risk-averse behaviour, especially if the consequences of an adverse outcome could be catastrophic. Those producing crops in agrarian economies or where economic activity is dependent on climate or ecological conditions will face a high level of uncertainty. Anything that lessened uncertainty could be expected to have a beneficial effect on higher-yielding investment, innovation and purposive decision-making.

Security arises from being able to deal with shocks, hazards and uncertainty. Although it will not be argued at length, it is a premise of this article that basic economic security is essential for freedom and development, and would enhance the pursuit of 'dignified work'. Basic economic security is defined as a threefold set of circumstances.

It requires limited exposure to idiosyncratic, co-variant and systemic risks, uncertainty, hazards and shocks. It requires an ability to cope with those if they materialize. And it requires an ability to recover from those outcomes. It is this last factor that has been insufficiently emphasized, and relates to the idea of livelihood regeneration and thus 'dignified work'.

The relevance of disaggregating economic insecurity is that the main forms have changed in the Global Transformation. Systemic insecurity and shocks have become much more common, while the contingency risks that were covered by selective social security have become secondary. This raises questions about the appropriateness of the most popular selective schemes for increasing income security. 
Before continuing, a further set of distinctions should be made. We may say that a scheme is universalistic if it is intended for all the population as a right, though perhaps based on citizenship or long-term residence. A scheme is targeted if it is intended for a specific group, defined by a test of eligibility, be it poverty, age, employment capacity or whatever. A scheme is selective if it uses specified criteria to determine eligibility, such as a means test or a 'proxy means test'. A scheme is conditional if it requires some specified behaviour, usually work-related, on the part of the intended recipient, or in some cases, the family members of the recipient.

In practice, there are instances of targeted universalistic schemes, in that all belonging to a social group are made eligible regardless of their means. An example is the universalistic social pension, which operates in several countries, such as Namibia and Mauritius. More common at present are targeted selective schemes, whereby the intended beneficiaries are defined by their social group (for example, women with young children) and by their poverty (having an income or assets below some threshold value).

In this regard, means - testing has come in for a great deal of criticism because of the difficulty of applying meaningful tests in developing countries, where establishing a person's income is very difficult, especially as it is likely to fluctuate erratically and substantially. Such tests are not only inequitable, but often prevent low-skilled workers, in particular, from being able to take up work opportunities, through what are known as poverty traps or unemployment traps. As discussed elsewhere (Standing, 2008), 'proxy' means-testing fares no better. Given their manifest drawbacks, backed by vast empirical evidence, it is remarkable that so many economists and others have continued to support means-tested schemes.

If universalism is about freedom and equality, then we may say that basic security is the essence of full freedom, drawing on the terms made famous by Isaiah Berlinnegative liberty (absence of restraints and unchosen controls, so giving autonomy) and positive liberty (opportunity and capacity to make rational choices). Neo-classical economists, neo-liberals and neo-cons focus on negative liberty when talking about freedom. Egalitarians should focus on both forms. However, they should be careful about the language of choice. Freedom is not just about making a choice between consumer goods or jobs. It is about being in situations where it is feasible to make choices about how to be ethical.

This leads to three dimensions of security. First, if we accept that security is the base of full freedom, we should accept that "dependent security" or paternalism is incompatible with security or freedom. If someone is dependent on the good will or discretion of a potential benefactor, be it a relative such as a husband, a landlord, a moneylender or the state, that person cannot have full freedom. This is crucial. For too long progressives have spoken about equality and freedom as if they were in competition. In the early twentieth century, social democrats took the wrong course and fell into their self-made trap, by allowing freedom to be constrained ostensibly in the interest of equality. They never trusted the intelligence of the working classes 
they purported to represent and love. In the process, they lost the debate on freedom to the political right. This led to the triumph of Hayek in the 1970s, paving the way for neo-liberalism, when freedom became defined as little more than the ability to compete.

There should be a presumption that paternalism is incompatible with real security, unless there is proof that specific forms of behaviour would be harmful to others, or that particular groups need protection because it has been demonstrated that they cannot provide it themselves, as with the case of children, the mentally incapacitated and the frail elderly. Even in those cases, the burden of proof should be placed on the paternalists.

Second, security is not an individualistic agenda about individual autonomy outside a socio-institutional context. It depends on possessing a sense of identity-I am a somebody, with self-respect, with desirable relationships and capabilities, in selfcontrol-but in a specific social context. In the era of Polanyi's Transformation, people were encouraged to identify themselves by their industrial class. They drew social entitlements from whether or not they were employees in the standard employment relationship. It may have been a form of alienation, but a sense of identity existed. The vision was of individuals belonging to a class. The challenge now stems from the fact that the vision of an industrial working class has faded into the history books.

Third, security requires a sense of social solidarity, requiring institutions of reciprocity and mechanisms to strengthen what Aristotle called philia, civic friendship. This was glossed over in social democracy, with the presumption that trade unions, industrial enterprises and collective bodies representing employers were sufficient. We will come back to that later.

If universal security is about freedom, identity and solidarity-or communityone should acknowledge a caveat, which underpins what might be called the dialectics of security. What is at issue is a claim right to universal basic security, not total security. One can have too much as well as too little. Excessive security may lead to indolence, irresponsibility and opportunism. This is one reason for favouring a cap on incomes and wealth. Usually, the damage that a very rich madman can do is much greater than the damage that a poor man can do. What we should argue for is universal basic economic security.

Now, suppose that one is an egalitarian and that one subscribes to the view that universal basic security is the objective. Are there any criteria compatible with egalitarianism and universalism by which we could evaluate all policy proposals and institutional changes? Let me propose five Policy Decision Principles, drawing from several philosophical traditions.

\section{The Security Difference Principle}

A policy or institutional change is socially just only if it improves the security and work prospects of the least secure groups in society. 
This is a starting point, even if it invites Paretian-type concerns about inter-personal comparisons. An egalitarian can assert that if equal basic security is the primary objective, then reducing the insecurity of the most insecure groups should have priority, and any action that worsens their security should be regarded critically. So, for instance, if a policy boosted the job opportunities of middle-income groups while worsening those of more disadvantaged groups, that could not be justifiable unless the losers were compensated in ways they found acceptable. The Security Difference Principle stems from Rawls (1973), who, from a liberal philosophical perspective, argued that social and economic inequalities are socially just only if they allow for the betterment of the worst-off groups in society.

Whether or not one accepts the Rawlsian perspective, in general, this principle can stand as a moral precept. A policy should be judged by whether it helps the least secure. If it does not, one should be uneasy (especially if it benefits others who are less insecure), unless some other principle is recognized that is demonstrably superior. If so, it would be up to the policy proponent to show that the alternative policy would yield superior outcomes. A key point is that there should be a right to a minimal amount of resources so as to enhance the capacity to develop and exercise effective freedom.

\section{The Paternalism Test Principle}

A policy or institutional change is socially just only if it does not impose controls on some groups that are not imposed on the most free groups in society.

This principle is ignored by too many donors and analysts working comfortably in affluence. Paternalism is rife in the design and implementation of social protection policies, and has been re-packaged under the rubric of 'libertarian paternalism'. It has worrying overtones of a Benthamite 'panopticon' society and the techniques of social control analysed by Michel Foucault (Thaler and Sunstein, 2008). Paternalism will be the biggest intellectual challenge for egalitarians.

According to this principle, forcing people to do certain forms of labour or 'jobs' when others are not forced to do them would be counter to social justice, even if the government authorities genuinely believe that the policy would be for the material betterment of those required to do them. Underlying this principle is the Millian liberal view that there is a prima facie case against paternalism (except in the case of young children and the medically frail), particularly against those forms that constrain the freedoms of the disadvantaged.

Among other aspects, this principle requires that all groups who could be subject to paternalistic direction should be enabled to have an effective independent Voice (collective and individual) in order to represent their interests. Only with such Voice can people have some semblance of control over their work and lives, and only if they have control can there be any decent meaning in the ideas of universalism and dignified work. 
Relevant to this principle, recent research on happiness has reiterated that people who have control over their work and life are happier than others, even taking account of the influence of access to benefits (Haidt, 2006). Control means having the capacity and opportunity to make decisions for oneself, without that being determined by the state, or by patriarchal figures or religious or other institutions that dictate how people must behave.

This principle is particularly important when considering how some governments, including recent American, British and Australian governments, have gone about achieving social integration through welfare reforms. It is about 'effective' or 'full' freedom, for which basic economic security is essential. It also relates to the notion of identity.

Certain groups have identity thrust upon them, and these tend to seek out a dependent situation that is scarcely enviable or what could be meant by basic security. Consider 'the supplicant beggar'. Surely, no sensible observer could regard such a person as secure, because even if he were able to occupy the same corner every day where three benefactors passed by and placed coins in a hat, there would be no moral bond associated with the charitable act, only humiliation. A beggar must be careful not to dress too well, beg too aggressively or show insufficient gratitude. The identity and the agency being shown are those of dependent insecurity.

A peasant migrating into an urban economy may rely on a network of patrons, intermediaries and brokers (the mastaan of Bangladesh, for example), who may provide the means of acquiring a job. Again, this is dependent insecurity, because what is given can be taken away, with interest. Mafioso patrons offer this. They play on insecurities and manipulate those enticed into their net. Gangster social protection flourishes in all market societies that universalize insecurity and foster chronic inequality.

Public works are a benevolent form of the supplicant beggar situation. So is the philanthropy by the super-rich, the elite of the global order. This leads to the next principle.

\section{The Rights-Not-Charity Principle}

A policy or institutional change is socially just if it enhances the rights of the recipient of benefits or services and limits the discretionary power of the providers.

This principle is also crucial for assessing the appeal of alternative security-enhancing schemes, and is particularly relevant in South Asia. A right is possessed as a mark of a person's humanity or citizenship, and cannot be made dependent on some behavioural conditionality. People should not be expected to have to plead for assistance in times of need, or to rely on the selective benevolence of civil servants or politicians. Their social entitlements should be rights, not matters for the discretionary decisions of bureaucrats, philanthropists or aid donors, however wellmeaning those may be. Charity is akin to pity, and pity is akin to contempt. A 
universalistic approach is one that emphasizes compassion and strengthens social protection through social solidarity and patterns of reciprocity.

The 'right to work', much asserted for the past two centuries, is particularly relevant here. If there is such a right, then there must be an obligation on somebody to provide work. But who or what is that person or organization? And how could someone ensure that others respect his or her 'right'? One cannot sensibly say that there is a right for every person to be given a job of their unrestrained choice. Not everybody can be President or Chief Executive. But should someone who is employing others be obliged to provide them with jobs? The very idea is nonsense.

What one could defend is the principle that everybody should have a claim right to have an equal good opportunity to pursue and develop their work capabilities. This equality of opportunity requires policies and institutions to enable everyone to develop their capacities equally, should they wish to do so. Guaranteeing people 'jobs' they do not want is scarcely an affirmation of any right to work. But creating the space, the security, for them to pursue a dignifying working life surely is.

In this regard, there is much merit in Article 1 of Title 1 of the Charter of Emerging Human Rights adopted at the Barcelona Social Forum in November 2004, drawn up by an international group including representatives of all the relevant UN bodies. This asserts the right to existence under conditions of dignity, comprising rights to security of life, to personal integrity, to a basic income, to healthcare, to education, to a worthy death and to work, defined as:

"The right to work, in any of its forms, remunerated or not, which covers the right to exercise a worthy activity guaranteeing quality of life. All persons have the right to the fruits of their activity and to intellectual property, under the condition of respect for the general interests of the community."

In sum, policies and schemes should be evaluated by whether they strengthen or weaken movement towards the realization of these rights, with those strengthening them being preferable to those that do not.

\section{The Ecological Constraint Principle}

A policy or institutional change is socially just only if it does not involve an ecological cost borne by the community or by those directly affected.

Ecological security is something most of us can understand. Smell the air, taste the water, look for the disappearing species that have shared our world. We are under threat, and anybody denying the evidence deserves scorn.

This policy decision rule is a quintessential twenty-first century principle. The potential ecological consequences must be built into the policy, not be put as an afterthought. For instance, there may be a trade-off between the generation of extra jobs and the ecological revival of a local area. Does a short-term growth maximization strategy benefit most of the people living in a country? The commercial drive to 
pursue growth and profits without taking into account social externalities is a recipe for global ecological disaster.

For evaluation purposes, an ecological constraint principle means that any policy, such as transfer schemes or job creation schemes, should be subject to the constraint that they should not deliberately or carelessly jeopardize the environment. For instance, one could argue that subsidies intended to boost skills, employment or jobcreating investment should be modified to promote only ecologically beneficial work and skills.

The ecological constraint principle raises emotional reactions, with claims that any such condition is a protectionist device that penalizes developing countries, forcing them to slow economic growth and incurring costs that hinder development. Regrettably, global warming and other forms of pollution-including many emanating from poor working conditions in the specious interest of job promotionwill hurt many more people in the developing countries and do so more devastatingly than in rich countries. The principle must be respected everywhere.

One issue should be confronted by this principle. The globalizing market economy is awash with selective subsidies, many going to rich companies and rich individuals. It has been estimated that in developing countries over 6 per cent of GDP goes to corporations. In many countries, including India, some 3 per cent of GDP goes in fuel subsidies, which pleases firms that rely on fuel and consumers whose living costs are held down. But they are neither environmentally or economically sensible nor universalistic. Subsidies encourage waste, an inefficient and excessive use of the resource in production, and excessive and inefficient use in consumption. Egalitarians should be appalled. There are high Type A and Type B errors; the benefit goes to many people who have no need, and it does not reach many who are in need. If one were concerned with 'the poor' or the insecure, then it would be more efficient and equitable to give the money directly to the citizens to cover the extra fuel costs that would come from charging a proper market price. This would have the virtue of leaving it to the citizen to make choices about how to spend a scarce resource.

\section{The Dignified Work Principle}

A policy or institutional change is just only if it does not block people from pursuing work in a dignified way and if it does not disadvantage the most insecure groups in that respect.

To some degree, this is incorporated in the Rights-Not-Charity Principle. However, the two-part test in this principle involves two value judgments-that work that is dignifying is worth promoting (whereas deterioration in working conditions or in opportunities would not be), and that the policy should enhance the range and quality of work options of the most insecure groups relative to others, or more than for others. While this may seem complicated, the main point is to determine whether a scheme favours the development of more freely chosen work opportunities and work capabilities. 
In sum, policies and institutional arrangements can be evaluated using five policy principles. Identifying trade-offs and setting priorities should be made transparent and subject to democratic processes. Policies that satisfy all the principles would be ideal. Although a comparative assessment of policies might be based on more than the five, they may be regarded as a coherent set of principles consistent with a belief in complex egalitarianism, in which the expansion of full freedom requires basic economic security for all.

\section{WHY INDUSTRIAL CITIZENSHIP FAILED}

The dominant socio-economic models of the twentieth century-social democracy and state socialism-promoted neither universalism nor freedom. They promoted certain forms of security, but these were unsustainable and divisive. Although this has been analysed at length elsewhere, it is perhaps useful to identify those aspects that need to be addressed in building a new progressive agenda. ${ }^{1}$

The models were built on the values of labour, and stemmed from a mode of thinking drawn from observing the process of industrialization in the nineteenth century. In Polanyi's terms, the era of disembeddedness led to mass insecurity and chronic inequality. To resolve the resultant crisis, a double movement took place, involving the creation of mechanisms and policies to promote seven forms of labourbased security (see Box 1).

The drawback was that linking the security to labour was actually inegalitarian and freedom-constraining. Industrial citizenship gave priority to labour market security and employment security, the two forms that favoured what was known as the industrial working class, but which really comprised manual employees in full-time wage labour. The vital forms of security in any progressive agenda should be income

\section{Box 1: Forms of Labour-based Security}

Labour market security-Adequate income-earning opportunities; at the macro-level, epitomized by a government commitment to Full Employment;

Employment security-Protection against arbitrary dismissal, regulations on hiring and firing, imposition of costs on employers for failing to adhere to rules, etc.;

Job security-Ability and opportunity to retain a niche, an occupation or 'career', plus barriers to skill dilution, and opportunities for 'upward' mobility in terms of status and income, etc.;

Work security-Protection against accidents and illness at work, through, for example, safety and health regulations, limits on working time, unsociable hours, night work for women, etc., as well as compensation for mishaps;

Skill reproduction security-Good opportunity to gain and retain skills, through apprenticeships, employment training, etc., as well as the opportunity to make use of competencies;

Income security-Assurance of an adequate and stable income, protection of income through, for example, minimum wage machinery, wage indexation, comprehensive social security, progressive taxation to reduce inequality and to supplement low incomes, etc.;

Representation security-Possession of a collective voice in the labour market, through, for example, independent trade unions, with a right to strike, etc. 
security and voice or representation security. But these were interpreted in a particular way, being linked to the performance of labour, that is, minimum wages, labourbased social security and industrial collective bargaining. The outcome was a process of fictitious labour decommodification, because workers were made dependent on remaining locked in the labour market in order to receive socio-economic security (Standing, 2007).

The models were alternative agendas for industrial citizenship, since the pattern of social solidarity being promoted was associated with performance of industrial labour. The social democratic variant was built on a system consisting of labour law, protective regulations, collective bargaining, progressive fiscal policy and labourbased social security. Most of those were contrary to an ethos of universalism.

Thus, labour law existed alongside common law; it removed the presumption of equality between contracting parties, on the grounds that workers were the vulnerable party vis-à-vis 'capital'. But labour law protected employees in the SER, not all workers. It divided the working population into deserving and undeserving groups. Labour regulations had the same divisive character, as did collective bargaining. Worst of all, the social security systems espoused by Beveridge and Bismarck and their progeny hinged on the performance of labour. They were as much a disciplinary regulatory device as they were geared to universal income security. When the Global Transformation began, they ceased to function efficiently or equitably, and labour-based social security has been withering ever since.

The industrial citizenship model of social democracy cannot and should not be restored. Any model of labourism was bound to be stultifying. But the key development is that its collapse has accompanied a growth in inequality, partly associated with a restructuring of social income, in which non-wage forms of remuneration to workers have been shrinking, while reliance on money wages has increased in a process of labour recommodification. This has concealed the full extent of the growth of income inequality, especially as privileged groups have been gaining non-wage benefits, from their corporations, the state or from the stock exchanges, while employees have been losing enterprise and state benefits.

The starkest stylized fact is the growth of functional income inequality. The returns to labour have gone down, and the returns to capital have gone up. There are wellknown reasons for this, including the fact that the bargaining position of those performing labour has steadily weakened while the bargaining position of owners of capital has sharply increased. While profits have risen, real wages have stagnated or declined, as they have in Japan, the USA, France and Germany, to name just a few countries struggling to maintain workers' living standards.

Behind that shift is the huge increase in global labour supply that has come with economically open economies, in particular from the emerging industrial workshops of the world, boxed together, ironically, as 'Chindia', along with a few other countries such as Brazil and Vietnam. The context in which to consider any progressive response is the strong prospect of a continuing growth in the strength of financial 
capital, coupled with continuing erosion in bargaining capacity on behalf of those depending on wages for their income security. That might be challenged in the longer term, but a progressive would surely be well advised to take those current realities as given for the foreseeable future.

If that is so, one may well argue that the existing distribution system is unsustainable. The growing inequalities and the associated social and economic insecurities could foment such social discontent and self-destructive anomic behaviour that even the winners will be ready to make concessions in the interest of stability and sustainability. What will be on offer? Before coming to the beginning of an answer, it might be worth recalling the emerging global class structure, which highlights the nature of the challenge facing those wishing to promote a freedomenhancing universalism.

\section{THE CLASS STRUCTURE IN THE GLOBAL TRANSFORMATION}

We cannot realistically think of any progressive strategy without taking account of the class structure associated with the Global Transformation. Class has not gone away just because Marxism has been marginalized. There are groups in society with distinctive relationships with the key assets and with distinctive sources of income, status and security.

We may take as given the well-identified rural class structure. But the world is being divided into a new global class pattern. ${ }^{2}$ At the top is a tiny elite of 'global citizens', with scarcely imaginable wealth counted in billions or hundreds of millions of dollars. This super-wealth is obscene. And yet one will look in vain for a policy agenda that sets out a strategy to combat the mechanisms that produce this obscenity. Discreet silence is the order of the day. That should stop.

Below that elite, in terms of income, status and economic security, are the salariat and a growing body of what may be called proficians, the former having employment security and access to extensive employment-related benefits as well as high salaries, the latter trading off employment security for income and occupational freedom through a work-style of consultancies, short-term contracts and multiple work activities. Many of the growing number of professionals around the world fit into one or other of these groups. They are economically and psychologically detached from the mainstream regulatory labour and social security system, with access to private and/or corporate benefits and privileges.

Below them in the emerging structure is a category that is rapidly becoming a misnomer, core employees (or workers), those who are mainly doing manual jobs in stable wage-labour relationships. They constituted the main part of the working class for which welfare states were designed. They were expected to become the majority group everywhere. Since the onset of the Global Transformation, their numbers have been shrinking everywhere, and their securities have shrivelled. The idea of 'the end of the working class' is not too fanciful. 
Many who would have entered or remained in the core have drifted into the next category, which has been growing hugely in the world economy. This is what should be called the precariat. The term 'informal sector' is inappropriate, for many reasons. What we are seeing is the spread of precarious labour relationships within and around even the most 'formal' of enterprises and organizations. Those in the precariat have no control over their working lives, and are subject to several forms of commodification. ${ }^{3}$

Finally, there are the unemployed and those detached in a miserable existence long known as a lumpen proletariat, consisting of anomic, socially detached people living semi-human lives. Many are the victims of a competitive, individualistic society.

The precariat is where social policy should concentrate, focusing on ways by which it could obtain income and representation security and, crucially, basic control over livelihoods and occupations. In the longer term, the goal should be to make the lifestyles of those in the precariat more like that of the proficians now. At the moment, the precariat is not just precarious in terms of income and access to jobs. It is insecure in not having control over its identity and it lacks agency. Unlike proficians, those in the precariat do not have a sense of occupation, in that they cannot control the way they combine work and leisure activities to develop their human capacities. A worthy universalism would be one that enabled them to have control over their own lives.

\section{BUILDING OCCUPATIONAL CITIZENSHIP}

The normative vision behind this article is that the way forward is to move from a model of industrial citizenship to one of occupational citizenship, building up social protection systems, redistributive systems and regulatory mechanisms around work and occupation, rather than the performance of labour. The emerging 'class' structure is the context in which that has to be attempted.

In order to revive egalitarianism and universalism, there must be a proper respect for freedom. This should move beyond liberal versions that emphasize autonomy as the absence of constraints and the existence of opportunities to participate in the labour market and make money. Freedom is also about being in situations of being able to be ethical. This is why institutions and associations are needed to give meaning to social solidarity and community. Certain types of identity such as those based on the nation state, or caste or religion, are too diffuse and closed to be reliable engines of ethical behaviour. Society needs associations that are committed to the generation and reproduction of human capacities. Those who understand the need for mechanisms of solidarity and reciprocity should wish to encourage the growth of the types of associations that could induce people of all walks of life to give respect to reproductive work as much as to commercially profitable activities that we economists have over-emphasized.

In that context, consider where we stand. The story of the shrivelling of industrial citizenship and the dismantling of the old pattern of labour security in the twentieth 
century is a painful one. The question now is: "What should replace the labour-based model that underpinned it?" The answer lies in moving away from the values of labour to the values of work. The human being wants and needs to work, both for productive and reproductive reasons and for creative, Promethean reasons. The normative vision that should surely guide us is that everybody should have the right to develop themselves through their working lives, through applying their minds, hands and bodies to improving themselves as human beings and in contributing to human society, through the care they provide to others and the support they give and receive.

The idea of occupational citizenship is beginning to take shape. An occupation necessitates the opportunity to develop one's perceived vocation, in which the productive, reproductive and creative aspects of work come to the fore. The trouble with this perspective is not that it is hard to grasp, but that it leads sophisticated minds to dismiss it as abstract and unrealistic. Go around India and you see wretchedness and people struggling to survive. Go around the USA and you see frenzied consumers amidst alienated, anomic individuals. Go around Brazil and numerous other countries, and you see tensions and violence amid squalid deprivation. In such circumstances, a vision of how work could be organized is easily dismissed as interesting but largely irrelevant to today's challenges. I disagree.

The originator of the vision was born well over 2,000 years ago, when the level of material income was a fraction of today's in any part of the world. Aristotle gave pride of place to civic friendship and realized that if we wish to live the Good Life we must care about the other. Work is a social activity. An occupation values civic friendship, or what Aristotle called philia - wishing well for the other, not for your sake but for his or hers, and sharing the values and goals of the other (Schwarzenbach, 1996). In a labour market, there is no intrinsic place for friendship. Each individual is encouraged to see himself or herself as being in competition with other individuals. If a person is inclined to lower the wage at which he or she will do a task, someone else loses or has to follow. The competition is necessarily aggressive. By contrast, in an occupation, there is or should be a place for civic friendship. One can admire another's workmanship, share the craft ethic, and value a shared sense of identity. There is an intrinsic psychic value for the work and the social relations in which the work is embedded.

For Aristotle, the perfect civic friendship was 'character friendship'-a love for the goodness of the other person's whole character. ${ }^{4}$ This is why he regarded the reproductive activity of mothers so highly. This is also why the ideal occupation is one in which there is a place for the work of care, in which the primary objective is to help a person become or remain an independent, mature equal capable of making ethical judgments and of participating in balanced and structured reciprocities.

Reproduction should be construed as the activity of "bringing another person into being". If conceived in this way, the idea of reproduction gives a proper place to altruism, which stands in conflict with paternalism, with the latter implying the reproduction of my norms and expectations (or norms not chosen by yourself), rather 
than facilitating and encouraging your capacity to define your own norms and expectations.

Work that is occupational in character allows rational decision-making by the person doing it. To be rational, one has to be able to direct oneself (a Kantian principle). This is part of full freedom (Taylor, 1984, p. 107). It stands resolutely against the 'libertarian paternalism' that is currently sweeping through social, labour market and economic policy, addling the brains of some distinguished academics as it does so, including two leading advisers to Barack Obama in the US Presidential election of 2008 (Thaler and Sunstein, 2008).

In labour markets, people are effectively coerced by prices; in a true occupation, people are motivated by dignity and morality, and by a sense of civic friendship. Ethical mores emerge through traditions and sociability, the culture of a craft and a craft community. They should not be enforced by the state. As Kant argued:

"For [a political community] to coerce its citizens to enter an ethical community with each other would be a contradiction in terms, for the latter involves in its very concept freedom from coercion... But woe to the legislator who would wish to bring about through coercion a constitution directed to ethical ends. For he would not only bring about the exact opposite of his ethical goals, but also undermine his political goals and render them insecure. ${ }^{15}$

This amounts to strong criticism of state paternalism, and implicit support for occupational citizenship. And yet paternalism is increasingly what is on offer from 'think tanks', advisers to politicians, political parties and social engineers posing as academics ${ }^{6}$.

Traditionally, occupations have involved both productive and reproductive aspects, binding practitioners together through civic friendship. But from the late eighteenth century onwards, a productivist bias created a breach between productive and reproductive forms of work. The error of labourism and the system of industrial citizenship, which reached its apex in the mid-twentieth century, was that it gave a strong bias to labour that produced goods, or that facilitated the production of goods, and systematically neglected reproductive work. An early contributor to this bias was Adam Smith, who classified occupations that were reproductive or service-oriented as unproductive labour, including the work of religious workers, doctors, men of letters, dancers, opera singers, actors and servants, whose work "perishes in the very instance of its performance" (Smith, 1981, pp. 330-31).

Kant too contributed to this nonsense, denying citizenship to those doing what we now call service work. More than a century after Adam Smith's faux pas, Arthur Pigou pithily identified another problem. He pointed out that if he hired a housekeeper, national income went up, as did employment, whereas if he then married her and she continued to do the same work, national income and employment went down. In other words, productive work was measured not by what you did but for whom you did it and on what terms. 
The silliness of the treatment of work and labour reached its peak during the twentieth century. Putting as many people as possible into jobs became the goal of social and economic policy, and the work of unpaid care and all the ethical activity involved in community work and voluntary work was simply discounted. The hegemonic labour force statistics made those forms of work invisible.

In the twenty-first century, we must rescue not only these forms of reproductive work but also the reproductive work that takes place inside occupations, seeing such work not only as nurturing and caring, as within the family, but also as involving acts of civic friendship that help to reproduce meaningful communities based on principles of sharing, reciprocity and social solidarity, or fraternity. An occupational community has always included a place for life-cycle reproduction and reciprocities. A labour market eschews such considerations.

Thinking in terms of occupations should lead to consideration of how people could choose the work they do in a way that would enable them to realize as much of their human capabilities and aspirations as possible, subject to the Kantian dictate that they should not do harm to others.

Of course, in translating that into an egalitarian agenda, one would need to add several caveats. But an agenda that began by wishing to promote opportunity to pursue the type of work people wish to do, would lead to quite different policies and institutional requirements than one wishing to maximize commercial production, wherein the worker is instrumental and the over-riding criterion is maximizing economic growth and GDP. The folly of the labourist model of social democracy was that individuals were treated as instrumental rather than as working people with needs, aspirations and capabilities that matter to them.

Now consider what occupation implies. We all exist with bundles of interests and capabilities. In our working lives, we look back to traditions of crafts and professions. But we should also look back to what has been taken away from the idea of dignifying work by the hegemony of capitalist labour organization.

For the ancient Greeks, the only work worthy of citizenship was that associated with civic friendship, which meant work in and around the house with close friends and relations, mixing with fellow citizens. By the Middle Ages, the guilds had emerged to provide institutional security for those in specific occupational communities. The guilds existed as societies within a society, giving their members a network in which reproductive and social work could co-exist with directly productive work. The guilds had their shortcomings, being hierarchical and prone to conservatism, but they retained for their members a control over the diverse activities encompassed by the occupation coupled with recognition of social reciprocity and mutual dependence, essential attributes of citizenship.

What is happening in the middle phase of the Global Transformation is that, while labour recommodification is taking place, occupations are being restructured and made subject to international, national and sub-national regulation. People may 
seek an occupational identity - I am an economist, a dentist, a teacher, and so on-but they have to do so in conditions where their control over their work trajectories is constantly under threat, if not absent altogether, as in the case of most of those in the precariat. The main reason for this is that occupations are in conflict with the market, which tends to commodify everything and to make all activities subject only to the dictates of competition and efficiency.

The challenges this dilemma poses can be appreciated by the recollection that the most dehumanizing aspect of the labourist model of the twentieth century was the systematic denial of the worthiness of work that is not labour. Smith and Kant may have had their predecessors, but they started the rot in mainstream social thinking in dismissing personalized service activities as unproductive. Alfred Marshall and Pigou understood the later manifestation of this way of thinking, but could do nothing about it. Besides the housekeeper-turned-wife aphorism, the stupidity of the modern way of looking at work can be illustrated by numerous realistic scenarios. For instance, if two people have adjoining gardens and agree that one should do the digging for both gardens, whereas the other would do the harvesting for both, they could be considered to be 'working', whereas if each did their own garden only, their work would not be counted in economic or labour market terms.

Throughout the ages, the definable occupations—crafts and 'professions'-have stood against labour commodification. They have done so by creating and defending occupational communities. In the Middle Ages, building on much earlier models, occupations were shaped in guilds in the towns and cities of Europe. Such organizations have always existed in various forms in Europe, China, India and elsewhere, giving their members a strong sense of community, status and identity. The attack on modern variants of occupational guilds in the globalization era has been increasingly successful. The attack has been conducted in the name of claims about competition. But occupational communities are required to give space for craftsmanship, 'professionalism', work ethics, and forms of learning and sharing.

\section{AN AGENDA FOR DECOMMODIFICATION}

What would a strategy for occupational security and citizenship look like? The normative vision is that a Good Society would be one in which more and more people were able to pursue their own sense of occupation in conditions of equal basic security.

We need to start by accepting that the market economy will remain dominant for the foreseeable future. We should go further, and accept the fact that labour is a commodity, so that those supplying labour should be paid a money wage determined by individual and collective bargaining and through proper contracts.

A crucial step towards a universal and egalitarian society is to delink basic economic security from labour, by finding ways of providing everybody with basic income security. This is not some utopian dream. It is beginning in some countries, 
and it must start with the recognition that what is being proposed is moving towards a claim right to basic security. At the moment, many rich countries are moving away from the realization of that right.

First, labour law should be phased out and become part of common law. At present, around the world, labour law exists to protect employees in their dealings with employers. In the flexible labour process, this leaves out an enormous number of people who work, even according to conventional definitions of 'worker'. Attempts to extend the definition of 'employee', as recommended recently in Australia (Bromberg and Irving, 2007), are arbitrary, convoluted and almost certainly ineffective. Extension still leaves a dichotomy.

The trouble is compounded because the law blocks those pursuing occupations from coalescing to represent their member practitioners and to bargain on their behalf. As independent contractors, they run up against anti-trust rules of the market economy. In Canada, a special law was passed to allow freelance artists and 'editors' to organize and bargain collectively. The difficulty then is to identify the party with which occupational groups can bargain.

In practice, occupations-professions, in the main-have established legal 'rights' by means of licences and certification schemes, implemented by the state or legitimized by it. These are supposed to protect the consumer and the professional standards and ethics of the various occupations. But critics claim that licensing (requiring everybody wishing to practise work of a particular type to be licensed) interferes with the citizen's right to practise. In the USA, this has been depicted as contrary to the 14th Amendment of the US Constitution.

This problem is resolvable, partly by shifting to a certification system, instead of a licensing one. But that should be accompanied by stronger mechanisms to establish or maintain occupational associations governed by principles of deliberative democracy. There should be space for 'collaborative bargaining' between groups with diverse interests, including groups contesting the right to practise particular types of work.

Meanwhile, the social protection system should be developed in a way that could strengthen occupational citizenship. In the twentieth century, the main ways of funding social protection were through employment-based contributions and direct taxation. But what if the firm metamorphoses into little more than a centre of finance, technology and marketing, while contracting out labour functions to groups and individuals, proficians at the upper end and the precariat at the lower end, all regarded as 'independent contractors'? People will not feel that they belong to a specific firm, a specific industry or a specific job. Where will be their source of social protection? One possibility is that they will be able to look to their occupational community - a modern guild-created to serve the needs and aspirations of contributing members.

This could only be a second platform of a new social protection systemreplacing old-style social insurance. In other words, the occupational body would act 
as a source of both regulation and social protection. This could function equitably and efficiently only if it were underpinned by basic income security, a universal base.

A basic income scheme should provide just enough to give everybody the means to cover their basic needs, to give them a life of dignity. Basic means that it must be meaningful enough to enable an individual to say to those treating her badly, "No!" A basic income would, for the first time, give dignified meaning to the right to work.

Take a low-income country such as Namibia or India. If basic economic security were to come from an unconditional basic income grant, a second platform of income security might come from the construction of occupational social funds. These could be mainly financed by contributions from occupational practitioners-a form of social solidarity that is more realistic in a modern, flexible labour process. Such funds built within a community would put moral pressure on members to lower their risk exposure and to take care. New guilds could look like occupational cooperatives.

One lesson derived from the rise and fall of the twentieth-century labourist models is that no system of social protection can be sustained unless it builds on, and accentuates, a perception of legitimate social solidarity and reciprocity. That perception is likely to disappear if the contributors feel that they are paying too much or if the various class strata feel that they have a low probability of needing income support, or even worse, believe that they would not obtain support if it were needed. Inside an occupational community, there are winners and losers. But there is a relatively high probability of an appreciation of occupational reciprocity built on understandable and time-honoured ideas of fraternity, of civic friendship. This is a universalism worth building, for if we believe that humans are intrinsically equal, each and every person, with a few exceptions, should be able to find a place in an occupational community reflecting their human capacities.

Such a society must be built on the premise of universal basic security. In order to be good, people have to be trusted to be good. This is the fundamental rationale for moving steadily towards a society with a basic income. Nevertheless, a basic income can only be politically feasible if it is depicted as part of a comprehensive structure of income support and redistribution. This leads us to a third platform or tier. At present, there is no realistic prospect of the precariat receiving adequate incomes when they are in jobs and they have no adequate income protection when they are outside employment. It is also likely that more of those in core jobs will not be able to receive adequate incomes from their employment. The only way to redress the structural inequality between 'capital' and 'labour' is to redistribute the income going to capital away from a privileged minority to those working to produce the profits and the communities that bear the social costs of having profitable enterprises in their midst. And such communities, of course, could include virtual communities, should that seem appropriate.

The mechanisms of capital sharing must be linked to the occupational freedom agenda. In an open economy, raising tax rates on profit would risk capital flight, and would be hard to implement politically. There must be incentives to share the capital 
income. One way for achieving this might be for the state to offer subsidized liability insurance on condition that a predetermined part of the profits went into a social fund to be distributed to local communities in the form of social and development funds.

The process would be helped by the establishment of largely self-regulating, selfdeveloping occupational communities, which could produce and maintain a body of people with the skills and commitment needed to encourage productive investment. This could cover the vital area of 'capability development'. Instead of firms indulging in expensive and notoriously inadequate training schemes, it would be better to arrange for payment of an equal amount into occupational development funds, leaving it to the occupational communities to reproduce competent practitioners. This would be more likely to produce broad competencies and an efficient and progressive use of profit income.

Similarly, occupational communities may be better placed than conventional trade unions or companies for creating funds to provide contingency benefits for their members and their families, and could provide what would amount to private portable benefits. It would be up to them to deal with the moral and immoral hazards associated with their schemes, and they could erect appropriate governance structures, based on principles of deliberative democracy.

The essence of citizenship is rights, and this leads back to ideas of democracy. Occupational associations should be based on deliberative democracy and governance structures that could limit monopolistic behaviour and opportunism. There is a need to combat the blockage of occupational bargaining via anti-trust legislation.

\section{CONCLUDING POINTS}

Socio-economic analysis is always driven by a normative vision. We need a normative base-and an underlying theory of justice-to make sure that we focus on the concepts and categories that make sense for our concerns. In that regard, it is worth concluding by adding a note of caution about the overwhelming focus on 'poverty' and 'the poor' in mainstream reports and economic analysis. The orthodox thinkers want us to focus on those notions. They do not want us to focus on the socioeconomic structures and processes, and the class configuration associated with them, let alone an egalitarian vision that blends freedom and equality.

By focusing on poverty, you can direct policy and political attention towards changing the features, attitudes and behaviour of 'the poor'. And very easily, you can fall into a trap of dividing this strange, much-measured group into the 'deserving' and the 'undeserving' poor, alongside the 'transgressing' poor, those who are not only 'undeserving' but who then go on to break the law in order to survive or improve their lot. Means testing goes in that direction, and so do the Benthamite libertarian paternalists that are currently dominating social and labour policy. 
A demand is placed on 'the poor', who were once seen as a 'target' group, that if they wish to be benevolently helped, by the state, by international donors, by the international financial agencies, by the 'rich', and by 'politicians', they must first demonstrate 'socially responsible behaviour'. There are 'no rights without responsibilities'! Selectivity, conditionality and an ethos of charity, rather than an agenda of real rights, soon build up. A vision of equality and universality should focus on class and the dynamics of distribution that are characterizing the ongoing Global Transformation, not on some disembodied notion of 'the poor'.

More generally, besides hoping for economic growth to trickle down to the poor or using fiscal policy in ways that seem unfeasible in the Global Transformation, there are three ways to reduce poverty, inequality and economic insecurity-the labour line, the commodity line (the provision of goods and services), and the cash line. India, like many other countries, has tended to prefer the first two and to disregard the third.

The first two approaches are necessarily and always selective. A government cannot guarantee everybody a job-and the language used to suggest that this is what is being intended when proponents talk of 'guaranteed employment', or in moments of euphoria 'full employment', is blatantly disingenuous, dishonest or naïve. What the proponents actually mean is a selective scheme to provide a selected social group with some labour in return for some remuneration, which usually means a bad job paying a bad income.

The arguments against the labour line have been well-rehearsed, and have not been effectively answered. Among the objections are their effect on the wages of 'unskilled' workers outside the schemes, and the claims that they involve large 'deadweight' effects (doing activities that would be done anyhow) and large substitution effects (displacing others doing such work). They also bring into question the principle that employment should be 'freely chosen', enshrined in various international conventions and declarations.

The second route to alleviating economic insecurity and poverty is the commodity line, whereby the state directly transfers goods or services, providing them either for free or at subsidized prices. Here too, the claims made by politicians can be deceiving. The criteria for selection make any such scheme far from universalistic, and as with selective employment schemes, they typically suffer from inefficiency through both Type A and Type B errors and market-distorting effects.

Implicitly, they assume that what the poor or the insecure lack is food (or whatever the good being provided). They have an economic failing in that they distort consumption patterns, inducing consumers to undervalue the goods being supplied and acting as a deterrent to the market provision of those goods. A vast amount of evidence also attests to waste, costly delivery and petty corruption. Except in emergencies, such schemes should surely not be used as a primary policy tool.

This leads to consideration of the cash line. If one favours a market economy but not a full market society, one is tempted to reflect on a saying of Confucius: "The 
easiest way out is through the door. Why do so few make use of it?"

If one believes that economic insecurity and poverty are primarily about a lack of assured command over resources and assets, the cash line offers at least a partial solution, which would become less partial if combined with interventions to redistribute key assets. Indeed, it would help if we could understand that providing people with assured cash payments would enable them to gain at least some control over the key assets of time and security, the loss of which is remarkably easy in a commercialized society.

As a way of lessening poverty and insecurity, cash transfers are defendable on several grounds. One is that they can boost the economy and generate livelihood opportunities. Another is that they do not involve the labour market and economic distortions that come with the labour and goods lines. They increase consumer demand where it is most likely to raise productive activity and employment, rather than where it is likely to raise the demand for imported 'luxury' goods. They enable beneficiaries to have not only a greater sense of security but also control over their lives, with an assurance that the basic needs of their immediate family will be met. For these and other reasons, they deserve fresh consideration, without the fancy paternalistic 'conditionality' with which too many cash transfer schemes have been burdened. However, above all, egalitarians should be pleased by their freedomenhancing qualities.

\section{NOTES}

1. For that analysis, see Standing (2002), and Standing (2009).

2. I am using 'class' in the classic sense of having specific relationships with 'means of production' and the state, which creates the main system of regulations, social protection and redistribution.

3. Using available statistics, I have estimated that about 25 per cent of the working-age population in South Africa is in the precariat there, and would guess that it is a higher and rising proportion of the workforce in other countries.

4. In the Nichomachean Ethics, he described a friend as 'another self'. Kant took exception to Aristotle's view, seeing the need to treat all others equally. Soren Kierkegaard, taking a Christian view, said friendships that exclude anybody are impermissible. This seems to mix friendship with the more diffuse notion of civility, which is a form of alienation, since civility produces no sense of liberation or social solidarity. Civility is not to be dismissed, but is limited to matters of process, whereas friendship is about substance as well. Civility is about how one treats strangers and about how one would wish to be treated by them. Friendship is about forging eudaemia, about intimacy.

5. Cited in Taylor (1984), p. 109.

6. The list of converts includes Julian Le Grand, who moved from the London School of Economics (LSE) and Bristol University to become a 'Downing Street adviser', to devise schemes for advancing 'paternalistic libertarianism' on behalf of Britain's New Labour Government. He wants to leave 'freedom of choice' but raise the costs of doing certain actions deemed unacceptable so as to encourage people to make the appropriate choices. 


\section{REFERENCES}

Bromberg, M. and M. Irving (eds.) (2007). Australian Charter of Employment Rights, Hardie Grant, Prahan, Victoria.

Haidt, J. (2006). The Happiness Hypothesis: Putting Ancient Wisdom to the Test of Modern Science, Basic Books/William Heinemann, New York.

ILO (2004). Socio-Economic Security Programme, Economic Security for a Better World, ILO, Geneva.

Rawls, J. (1973). A Theory of Justice, Cambridge University Press, Cambridge.

Schwarzenbach, S.A. (1996). "On Civic Friendship”, Ethics, Vol. 107, October, pp. 97-128.

Smith, A. (1981). The Wealth of Nations, Liberty, Indianapolis, Vol. 1.

Standing, Guy (2002). Beyond the New Paternalism: Basic Security as Equality, Verso, London.

- (2007). "Labour Recommodification in the Global Transformation", in A. Bugra and K. Agartan (eds), Reading Karl Polanyi for the Twenty-first Century: Market Economy as a Political Project, Palgrave Macmillan, New York, pp. 67-94.

— (2008). "How Cash Transfers Promote the Case for Basic Income”, Basic Income Studies, Vol. 3 (1), pp. 1-30.

- (2009). Work after Globalization: Building Occupational Citizenship, Edward Elgar, London.

Taylor, C. (1984). "Kant's Theory of Freedom", in Z. Pelczynski and J. Gray (eds), Conceptions of Liberty in Political Philosophy, The Athlone Press, London.

Thaler, R. and C. Sunstein (2008). Nudge: Improving Decisions About Health, Wealth and Happiness, Yale University Press, New Haven. 